\title{
KEPASTIAN HUKUM SERTIPIKAT HAK TANGGUNGAN ELEKTRONIK DALAM HUKUM PEMBUKTIAN DI PERADILAN MENURUT HUKUM ACARA PERDATA
}

\author{
Oleh : \\ Arkisman*, Nandatama Ayu Lafitri** \\ * Fakultas Hukum, Universitas Gresik \\ Email : arkismanfhug@gmail.com \\ ** Fakultas Hukum, Universitas Gresik \\ Email : nandalafitri@gmail.com
}

\begin{abstract}
ABSTRAK
Mengingat hasil dari sertipikat hak tanggungan yang dilakukan secara elektronik adalah dalam bentuk dokumen elektronik. Dokumen Elektronik dalam pembuktiannya dipersamakan dengan Dokumen tertulis (surat). Sehingga kedudukan alat bukti elektronik sebagai alat bukti sah yang dapat dipergunakan saat berpekara di pengadilan, yang dimana dalam pembuktiannya dalam perkara perdata dapat mengacu pada aturan yang sebelumnya telah mengatur mengenai alat bukti elektronik yaitu Undang-Undang Nomor 19 Tahun 2016 Tentang Perubahan Atas Undang-Undang Nomor 11 Tahun 2008 Tentang Informasi Dan Transaksi Elektronik. Sehingga sertipikat hak tanggungan elektronik tersebut memiliki kepastian hukum karena mendapat perlindungan dari Undang-Undang ITE No 11 Tahun 2008. Metode penelitian yang digunakan dalam penulisan ini adalah metode penelitian hukum normatif. Penelitian dilakukan dengan meneliti bahan hukum terkait yang dikumpulkan melalui penelitian kepustakaan. Jenis pendekatan yang digunakan ialah Pendekatan Konseptual, Pendekatan Perundangundangan, serta Pendekatan History (Sejarah).
\end{abstract}

\section{Kata kunci : Kepastian Hukum; Pembuktian; Sertipikat Hak Tanggungan Elektronik.}

Given that the result of a certificate of mortgage which is done electronically is in the form of an electronic document. Electronic Documents in proof are equated with written documents (letters). So that the position of electronic evidence as valid evidence that can be used when holding court in court, which in the evidence in civil cases can refer to the rules that previously regulated electronic evidence, namely Law Number 19 of 2016 concerning Amendments to the Law. Number 11 of 2008 concerning Electronic Information and Transactions. So that the electronic mortgage certificate has legal certainty because it is protected by the ITE Law No. 11 of 2008. The research method used in this paper is the normative legal research method. The research was conducted by examining related legal materials collected through library research. The type of approach used is the Conceptual Approach, the Legislative Approach, and the Historical Approach.

Key words: legal certainty; Proof; Electronic Liability Certificate. 


\section{A. PENDAHULUAN}

Pemberian kredit pada awalnya dilakukan dengan mengadakan suatu perjanjian, dalam perjanjian tersebut terdiri dari perjanjian pokok yang nantinya diikuti dengan perjanjian tambahan berupa perjanjian pemberian jaminan oleh pihak debitor. Dalam isi perjanjian tersebut tentunya memerlukan suatu jaminan yang digunakan untuk memberikan kepastian dan perlindungan hukum untuk para pihak yang terlibat didalamnya.

Jaminan yang diberikan calon debitor akan diikat dengan suatu hak atas jaminan sesuai dengan jenis jaminan yang diserahkan. Dalam praktik perbankan, jaminan merupakan langkah terakhir jika debitor tidak dapat melaksaanakan kewajibannya lagi untuk membayar kreditnya kepada bank, jaminan terebut dapat diambil alih dan kemudian dijual atau dilelang oleh bank setelah mendapat pengesahan dari pengadilan. ${ }^{1}$

Jaminan sendiri dibedakan menjadi jaminan perseorangan dan jaminan kebendaan. Namun dalam dunia perbankan jaminan yang sering digunakan adalah jaminan kebendaan. Jaminan kebendaan bisa berupa benda bergerak maupun tidak bergerak, jaminan benda tidak bergerak berupa tanah atau benda-benda yang berkaitan dengan tanah paling banyak digunakan sebagai agunan dalam perjanjian kredit bank berupa " hak milik, hak guna bangunan dan hak guna usaha dapat dijadikan jaminan hutang dengan dibebani hak tanggungan".Untuk menjaminkan hak atas tanah adalah dengan menjaminkan berupa surat-surat berharga/sertipikat tanah pada bank, yang disebut sebagai Hak Tanggungan. Dalam proses Hak Tanggungan yang diikat dengan Akta Pemberian Hak

${ }^{1}$ Riky Rustam, Hukum Jaminan, UII Press, Yogyakarta, 2017, h. 57
Tanggungan yang dibuat dan ditandatangani dihadapan Pejabat Pembuat Akta Tanah yang kemudian didaftarkan di Kantor Badan Pertanahan Nasional setempat. Di dalam sertipikat tersebut nantinya akan dibebankan jaminan berupa Hak Tanggungan yang saling mengikat antara pihak kreditur dengan debitor. Dalam pembuatan Hak Tanggungan, terdapat beberapa sifat yang melekat pada hak tanggungan tersebut, "sifat hak tanggungan tidak dapat dibagi-bagi, artinya hak tanggungan membebani secara utuh objeknya, dan setiap bagian daripadanya tidak membebaskan sebagian objek dari beban hak tanggungan, melainkan hak tanggungan tetap membebani seluruh objeknya untuk sisa utang yang belum dilunasi". ${ }^{2}$ Dengan berkembangnya kemajuan teknologi saat ini, Menteri ATR / Kepala Badan Nasional menerbitkan Peraturan Menteri Agraria Dan Tata Ruang/Kepala Badan Pertanahan Nasional Nomor 9/2019 Tentang Pelayanan Hak Tanggungan Terintegrasi Secara Elektronik yang dimana segala prosesnya dilakukan secara online atau elektronik. Dan hasil dari sertifikat hak tanggungan berupa hasil cetakan Dokumen Elektronik. Ketentuan mengenai alat bukti elektronik sebelumnya hanya diatur dalam hukum materiil seperti diatur pada Undang-Undang Nomor 11 Tahun 2008 Tentang Informasi Dan Transaksi Elektronik. Mengingat alat bukti elektronik belum diatur secara khusus dalam Hukum Formal khususnya hukum acara perdata sehingga alat bukti elektronik masih dipertanyakan validitasnya di pengadilan.Lantas bagaimana kedudukan alat buki elektronik dalam Hukum Acara perdata dan apakah ada kepastian hukum

${ }^{2}$ I Ketut Oka Setiawan, Hukum Pendaftaran \& Hak Tanggungan, Sinar Grafika, Jakarta, 2019, h. 102. 
mengenai sertifikat hak tanggungan elektronik yang berupa dokumen elektronik saat digunakan sebagai alat bukti di pengadilan. Adapun tujuan dilakukanya penelitian ini adalah untuk mengetahui tentang kedudukan alat bukti elektronik dalam hukum acara perdata dan kepastian hukum pembuktian sertifikat hak tanggungan elektronik di pengadilan menurut hukum acara perdata. Berdasarkan uraian latar belakang diatas maka penulis merasa tertarik untuk membahas mengenai "Kepastian Hukum Hak Tanggungan Elektronik Dalam Hukum Pembuktian Di Peradilan Menurut Hukum Acara Perdata".

\section{B. METODE PENELITIAN}

Di dalam penelitian ini, penulis menggunakan metode penelitian yuridis normatif yang dilakukan dengan cara menelaah teori-teori hukum, konsep hukum, asas-asas hukum serta mengkaji peraturan perundang-undangan yang berhubungan dengan pokok permasalahan yang telah dirumuskan dalam penelitian ini. Untuk mencari jawaban pokok permasalahan dalam penelitian ini, penulis menggunakan tiga pendekatan masalah antara lain Pendekatan Konseptual (Coceptual Approach), Pendekatan PerundangUndangan (Statue Approach), danPendekatan Sejarah (Historical Approach).

\section{PEMBAHASAN}

\section{Kedudukan Alat Bukti Elektronik Dalam Hukum Acara Perdata}

Hukum sendiri merupakan suatu aturan yang mengatur atau mengikat yang dibuat oleh manusia yang apabila dilanggar akan mendapatkan sanksi. Sebelumnya dalam lingkup dunia hukum, hukum sendiri terdapat beberapa pembagian dalam hal pengaturannya. Pembagian tersebut dibedakan menjadi hukum material dan hukum formal.
"Hukum Material adalah hukum yang menjelaskan perbuatan-perbuatan apa yang akan dapat dihukum dan juga hukuman-hukuman apa yang akan dapat dijatuhkan". ${ }^{3}$ Sedangkan pengertian Hukum Formal adalah "suatu hukum yang mengatur serta mengikat tata cara menjalankan dan mempertahankan peraturan yang ada pada hukum material". ${ }^{4}$ Salah satu bentuk dari hukum formal adalah hukum acara, salah satunya adalah hukum acara perdata. hukum acara perdata menurut R. Subekti adalah "hukum acara itu mengabdi kepada hukum materil, setiap perkembangan dalam hukum materil itu sebaiknya selalu diikuti dengan penyesuaian hukum acaranya. Oleh karena itu hukum perdata diikuti dengan penyesuaian hukum acara perdata dan hukum pidana diikuti dengan penyesuaian hukum acara pidana". 5

Dalam hukum acara perdata terdapat beberapa asas yang harus diperhatikan hakim dalam memutuskan suatu perkara di pengadilan. Asas pada dasarnya adalah suatu prinsip dasar yang menjadi acuan atau tumpuan dalam berpendapat ataupun berpikir dalam mengambil keputusan-keputusan yang penting dalam hidupnya. Asas ini digunakan oleh hakim sebagai pedoman atau dasar apa yang harus dilakukannya dalam mengadili suatu perkara. Adapun asasasas tersebut terdiri dari : Asas Hakim Bersifat Pasif; Asas Persidangan Terbuka; Asas Kedua Belah Pihak; Asas

\footnotetext{
${ }^{3}$ Mughnifar Ilham, "Pengertian Hukum Formil dan Hukum Materil", diakses pada tanggal 20 Juli 2020, h. 2.

${ }^{4}$ Ibid, h.2.

${ }^{5}$ Danginpuriandpartner, "Pengertian Hukum Acara Perdata Menurut Pakar”, Wordpress, diakses pada tanggal 20 Juli 2020, h. 1.
} 
Bebas Campur Tangan Para Pihak Diluar Pengadilan; Asas Beracara Dikenakan Biaya; Asas Putusan Disertai Alasan. Dalam berperkara di pengadilan khususnya dalam perkara perdata tentunya akan ada tahap yang dinamakan tahap pembuktian suatu perkara, pembuktian yang berarti membuktikan segala kebenaran untuk membela dirinya atas suatu perkara di pengadilan, saat tahap pembuktian ini harus dilengkapi dengan alat bukti yang sah untuk membuktikan dalil-dalil atas suatu kebenaran yang diketahuinya. Alat bukti tersendiri berarti segala sesuatu yang dapat dipakai untuk membuktikan dalil dalilnya saat berperkara di pengadilan yang sesuai dengan aturan dan ketentuan yang berlaku. Alat Bukti dalam hukum acara perdata ini diatur dalam Het Herzienne Indonesisch Reglement (HIR) serta Rechtsreglement Buitengewesten (RBg) yang juga sama diatur dalam Kitab Undang-Undang Hukum Acara Perdata (KUHPer). Macam-macam lat bukti dalam perkara perdata yaitu :

1. Alat Bukti tertulis (surat) : Surat atau tulisan merupakan alat bukti yang utama. Karena dalam lalu lintas keperdataan seperti adanya jual beli, sewa menyewa, utang-piutang dan lain lain, orang dengan sengaja membuat perjanjian tersebut secara tertulis dikarenakan akan digunakan sebagai alat bukti untuk membuktikan bahwa telah adanya perbuatan hukum yang telah dilakukan. Alat bukti surat ini dapat berupa akta otentik, akta yang dibuat dibawah tangan, dan juga akta yang bukan akta atau disebut juga sebagai surat biasa. Akta Otentik menurut Sudikno Mertokusumo yaitu "Akta yang bentuknya ditentukan oleh undangundang, dan dibuat oleh atau dihadapan pegawai-pegawai umum (pejabat umum) yang berkuasa untuk itu di tempat di mana akta dibuatnya". ${ }^{6}$

Sedangkan Selain Akta Otentik juga ada Akta Dibawah Tangan yang dibuat sengaja oleh para pihak yang berkepentingan untuk pembuktian tanpa bantuan dari pejabat umum yang berwenang. Segala akta yang tidak dibuat oleh atau dihadapan pejabat umum yang berwenang termasuk dalam akta di bawah tangan, seperti Surat Perjanjian jual beli di bawah tangan, surat kuasa dan sebagainya. Dalam akta dibawah tangan tentunya surat atau tulisan harus ditandatangani oleh para pihak, dan isinya yang menerangkan menyangkut perbuatan atau hubungan hukum, setiap surat yang ditandatangani tentunya dibubuhi dengan materai yang cukup yang ditindih dengan tandatangan basah diatasnya.

2. Alat Bukti Keterangan Saksi :Peranan saksi dalam suatu perkara adalah sebagai alat bukti untuk memberikan keterangan suatu perkara/peristiwa yang diketahui oleh saksi, yang nantinya keteranganketerangan saksi tersebut akan dijadikan pedoman oleh hakim, namun tidak semua keterangan saksi akan dijadikan pedoman.

3. Alat Bukti Persangkaan : Persangkaan pada hakikatnya merupakan alat bukti yang bersifat tidak langsung, karena alat bukti persangkaan tidak dapat berdiri sendiri melainkan harus dengan bantuan alat bukti lain. Dengan persangkaan artinya suatu peristiwa dibuktikan secara tidak langsung melainkan suatu persitiwa lain. 4. Alat Bukti Pengakuan : Pengakuan dimana seseorang akan memberikan pernyataannya atas suatu

${ }^{6}$ Efa Laela Fakhriah, Bukti Elektronik Dalam Sistem Pembuktian Perdata, Refika Aditama, Bandung, 2017, h. 16. 
perkara, pengakuan ini dapat disampaikan baik di hadapan hakim/di muka pengadilan maupun diluar pengadilan. Dalam pemberian pengakuan keterangan yang diberikan adalah keterangan sepihak tanpa memerlukan persetujuan dari pihak lawan. Apabila dalam pemberian pengakuan terbukti pengakuan tersebut tidak benar adanya maka hakim tidak perlu meneliti kebenaran pengakuan tersebut, sehingga pengakuan bukanlah sebuah penyataan tentang kebenaran akan tetapi suatu pernyataan kehendak untuk menyelesaikan perkara.

5. Alat Bukti Sumpah : Sumpah yang dilakukan di Pengadilan harus diucapkan dihadapan hakim yang memeriksa perkara dan dihadiri oleh pihak lainnya. Sumpah tersebut harus dilakukan/diucapkan sendiri tanpa diwakilkan atau diperantarakan oleh pihak lain. Dimana nantinya hakim akan menunjuk orang lain atau kuasanya untuk mengangkat sumpah yang diucapkan secara rinci dimana dalam pengucapannya disesuaikan berdasarkan keyakinan masing-masing,sumpah tersebut diucapkan dalam keadaan hikmat agar orang yang bersumpah timbul kesadaran dalam dirinya untuk memberikan keterangan yang benar.

Mengingat kehidupan manusia semakin hari semakin berkembang dalam berbagai sektor kehidupan, perkembangan tersebut tentunya bersamaan dengan perkembangan teknologi sekarang yang semakin mempengaruhi pola pikir manusia saat ini.Seiring dengan perkembangan dalam masyarakat mengenai teknologi dan informasi, timbul berbagai macam aktivitas yang mengarah pada elektronik, begitu banyak kegiatan dalam dunia elektronik. Sebelumnya mengenai pengaturan alat bukti elektronik sudah diatur dalam Tentunya muncul berbagai alat bukti dalam hubungan keperdataan seperti adanya kegiatan $e$ - commerce dan e-contract, dimulai dengan munculnya foto copy sampai dikenai dan digunakannya alat bukti elektronik.

Bukti elektronik yang dimaksud adalah berupa Informasi Elektronik dan Dokumen Elektronik, alat bukti elektronik dapat dikatakan sah apabila menggunakan system yang diatur dalam undang-undang, seperti dapat dijamin keutuhannya, kebenarannya, keasliannya dan dapat dipertanggungjawabkan atas tampilannya yang juga dapat diakses sehingga menerangkan suatu keadaan. Eksistensi alat bukti elektronik diakui sebagai alat bukti yang sah semakin kuat dengan adanya Undang-Undang No 11 Tahun 2008 Tentang Transaksi \& Informasi Elektronik (UU ITE) yang diatur dalam Pasal 5 ayat (1) yang berbunyi "Informasi elektronik dan /atau dokumen elektronik dan /atau hasil cetaknya merupakan alat bukti hukum yang sah", dan ayat (2) yang berbunyi : "Informasi elektronik dan /atau dokumen elektronik dan /atau hasil cetaknya sebagaimana dimaksud pada ayat (1) merupakan perluasan dari alat bukti yang sah sesuai dengan Hukum Acara yang berlaku di Indonesia".

Kedudukan Bukti Elektronik setelah Undang-Undang No 11 Tahun 2008 tentang Informasi Dan Transaksi Elektronik dalam pembuktian perdata mengenai alat bukti elektronik dalam hukum acara perdata memang belum diatur secara khusus, padahal sudah banyak ditemukan berbagai transaksi elektronik atau kegiatan yang dilakukan dengan bantuan elektronik sehingga menimbulkan masalah karena belum adanya kepastian hukum bagi masayarakat dalam melakukan perbuatan dengan menggunakan elektronik.Penggunaan video teleconference juga dikatakan sebagai bukti yang sah apabila dalam pemeriksaan saksi di pengadilan keterangannya sangat diperlukan dan 
saksi yang bersangkutan tidak dapat hadir dikarenakan satu dan lain hal maka dapat menggunakan video teleconference dalam bentuk tayangan gambar yang dapat berkomunikasi secara langsung dengan pemeriksa atau hakim dalam memberikan keterangannya tanpa harus hadir secara fisik di pengadilan. Sehingga alat bukti elektronik memiliki kekuatan sebagai alat bukti yang sah yang menandakan bahwa sesuai dengan keadaan atau kejadian yang sebenarnya yang dapat dijamin keasliannya.

Meskipun demikian, dalam beberapa peraturan baru sudah mengatur dan menempatkan bukti elektronik sebagai alat bukti seperti dalam UndangUndang No 8 Tahun 1997 tentang Dokumen Perusahaan yang diatur dalam Pasal 12 ayat (4) yang berbunyi "Dalam hal dokumen perusahaan yang dialihkan ke dalam microfilm atau media lainnya adalah naskah asli yang mempunyai kekuatan pembuktian otentik dan masih mengandung kepentingan hukum tertentu, pimpinan perusahaan wajib tetap menyimpan naskah asli tersebut".

Dalam Undang-Undang No 8 Tahun 1997 Tentang Dokumen Perusahaan Pasal 15 ayat (1) yang berbunyi "Dokumen Perusahaan yang telah dimuat dalam microfilm atau media lainnya sebagaimana dimaksud dalam pasal 12 ayat (1) dan hasil cetakannya merupakan alat bukti yang sah".Berdasarkan Undang-Undang No 11 Tahun 2008 Tentang Informasi Dan Transaksi Elektronik Pasal 5 ayat (3) ditentukan bahwa Informasi dan/atau Dokumen Elektronik dinyatakan sah apabila menggunakan sistem elektronik yang sesuai dengan ketentuan-ketentuan yang diatur dalam Undang-Undang Informasi Dan Transaksi Elektronik. Seperti yang telah diatur dalam UndangUndang No 11 Tahun 2008 Tentang Informasi Dan Transaksi Elektronik Pasal 5 ayat (1) yang berbunyi
"Informasi Elektronik dan/atau Dokumen Elektronik dan/atau hasil cetaknya merupakan alat bukti hukum yang sah".

Pengaturan alat bukti elektronik saat ini hanya diatur dalam hukum materiil bukan dalam hukum formal yang bersifat mengikat, maka sangat diperlukan adanya hukum formal yang mengatur mengenai bukti elektronik sebagai alat bukti yang sah untuk diajukan ke pengadilan guna tercapainya kepastian hukum dan menghindari adanya kekosongan hukum. Sehingga Kedudukan alat bukti elektronik sebagai alat bukti berdasarkan Undang-Undang No 11 Tahun 2008 Tentang Informasi \& Transaksi Elektronik sesuai dengan Pasal 5 ayat (1) yang menyatakan bahwa semua Informasi Elektronik \&Dokumen Elektronik beserta hasil cetakannya merupakan alat bukti yang sah, sehingga kedudukan alat bukti elektronik dapat dipergunakan dalam praktik perkara di persidangan sebagai alat bukti serta adanya perluasan mengenai alat bukti di luar Kitab Undang-Undang Hukum Perdata, namun tetap menjadi alat bukti yang sah apabila memenuhi syarat yang diatur oleh undang-undang.

\section{Kepastian Hukum Pembuktian Sertipikat Hak Tanggungan Elektronik (SHT EL) Di PeradilanMenurut Hukum Acara Perdata}

Setelah terbitnya Peraturan Menteri Agraria Dan Tata Ruang/Kepala Badan Pertanahan Nasional Republik Indonesia Nomor 9 Tahun 2019 Tentang Pelayanan Hak Tanggungan Terintegrasi Secara Elektronik segala proses mengenai pendaftaran proses hak tanggungan dilakukan secara elektronik melalui komputer dan website yang sudah disediakan, dalam proses tersebut tentunya sangat berbeda dengan proses yang sebelumnya, Mekanisme pendaftaran pelayanan hak tanggungan 
elektronik menurut Peraturan Menteri Agraria Dan Tata Ruang/Kepala Badan Pertanahan Nasional Republik Indonesia Nomor 9 Tahun 2019 adalah: Para pihak bersama ke kantor Pejabat Pembuat Akta Tanah (PPAT) dengan maksud hendak membuat Akta Pemberian Hak Tanggungan (APHT) dengan membawa berkas-berkas yang diperlukan; Pejabat Pembuat Akta Tanah (PPAT) melakukan pengecekan sertipikat pada pelayanan informasi pertanahan; Penandatanganan Akta Pemberian Hak Tanggungan (APHT) di kantor PPAT; Pejabat Pembuat Akta Tanah atau PPAT yang telah menjadi pengguna terdaftar dalam sistem elektronik Mitra BPN (Badan Pertanahan Nasional) menginput data APHT dan mengunggah APHT tersebut; Sistem akan mengeluarkan surat pengantar akta; Kreditur yang telah menjadi pengguna terdaftar mengajukan permohonan pendaftaran hak tanggungan melalui sitem hak tanggungan elektronik (HT el); Kreditur melengkapi persyaratan yang diperlukan dan membuat surat pernyataan mengenai pertanggungjawaban keabsahan dan kebenaran dokumen elektronik yang diajukan; Kreditur memperoleh tanda bukti pendaftaran kemudian melakukan pembayaran PNBP; Kantor Pertanahan melakukan pemeriksaan dokumen elektronik yang diajukan; Hak Tanggungan terbit; Kreditur dapat mencetak sertipikat yang diterbitkan oleh sistem serta mencetak dan menempelkan stiker catatan hak tanggungan pada sertipikat obyek hak tanggungan. Pengguna Layanan Sistem Hak Tanggungan Elektronik atau SHT el seperti yang tercantum dalam Pasal 7 ayat (1) Peraturan Menteri Agraria Dan Tata Ruang/Kepala Badan Pertanahan Nasional Republik Indonesia Nomor 9 Tahun 2019 adalah perseorangan /badan hukum selaku kreditur sebagaimana yang diatur dalam peraturan perundangundangan yang mengatur mengenai Hak
Tanggungan dan Aparatur Sipil Negara Kementerian yang bertugas melayani Hak Tanggungan, keduanya harus menjadi pengguna terdaftar dalam sistem Hak Tanggungan Elektronik, untuk menjadi pengguna terdaftar dalam sistem tersebut tentunya ada beberapa syarat yang harus dipenuhi seperti mempunyai domisili elektronik, surat keterangan yang terdaftar di otoritas jasa keuangan, pernyataan pemenuhan persyaratan dan kriteria serta persetujuan ketentuan sebagai pengguna terdaftar dan syarat lainnya yang telah ditentukan oleh Kementerian.

Penggunaan alat bukti elektronik secara sah semakin kuat semenjak diterbitkannya Undang-Undang Nomor 11 Tahun 2008 jo Undang-Undang Nomor 19 Tahun 2016 Tentang Informasi Dan Transaksi Elektronik seperti adanya dokumen elektronik, informasi elektronik beserta hasil cetakannya. Berdasarkan ketentuan yang diatur dalam Peraturan Menteri Agraria Dan Tata Ruang/Kepala Badan Pertanahan Nasional Republik Indonesia Nomor 9 Tahun 2019 Tentang Pelayanan Hak Tanggungan Terintegrasi Secara Elektronik menyebutkan bahwa sertipikat hak tanggungan nantinya berupa dokumen elektronik sesuai dengan pasal 14 ayat (2) bahwa hasil layanan sebagaimana dimaksud pada ayat (1) berupa dokumen elektronik yang diterbitkan oleh sistem HT - el.

Alat bukti yang berupa dokumen elektronik dapat dikatakan sah apabila menggunakan sistem elektronik yang sesuai dengan ketentuan yang telah diatur dalam undang-undang, serta dapat dipertanggungjawabkan keasliannya. Akan tetapi ada beberapa dokumen elektronik yang tidak dapat dikatakan sah untuk dijadikan sebagai alat bukti yaitu surat yang menurut undang-undang harus dibuat tertulis dan surat yang dibuat oleh pejabat pembuat akta atau dibuat dalam bentuk akta notariil. 
Permasalahannya adalah apakah suatu bukti yang berbentuk dokumen elektronik dapat dipersamakan dengan dokumen tertulis (surat) yang digunakan oleh para pihak dalam penyelesaian sengketa di pengadilan dan dapatkah bukti tersebut diterima oleh hakim. Mengingat dalam hukum acara perdata belum diatur mengenai alat bukti elektronik sehingga belum adanya kepastian hukum dalam pembuktian alat bukti elektronik saat berperkara di pengadilan yang juga menyulitkan hakim dalam memutuskan saat adanya perkara yang menggunakan alat bukti elektronik. Sejak lahirnya UndangUndang Nomor 11 Tahun 2008 Tentang Informasi Dan Transaksi Elektronik yang mengatur mengenai transaksi elektronik, bukti elektronik menjadikan dokumen elektronik beserta hasil cetakannya sebagai perluasan dari alat bukti yang sah, untuk mengetahui kekuatan pembuktian dokumen elektronik terlebih dahulu harus mengetahui kualifikasi dokumen elektronik tersebut. Bentuk dokumen elektronik sangat beragam, tergantung dari maksud dan tujuan dari adanya dokumen elektronik tersebut.

Sebagaimana yang diatur dalam penjelasan umum Undang-Undang Informasi Dan Transaksi Elektronik bahwa dokumen elektronik memiliki kekuatan pembuktian yang sama dengan dokumen yang dibuat diatas kertas atau secara tertulis yang sama halnya dalam bentuk surat. Menurut pasal 6 UndangUndang Nomor 11 Tahun 2008 Tentang Informasi Dan Transaksi Elektronik, dalam hal terhadap ketentuan lain yang diatur dalam pasal 5 ayat (4) yang mensyaratkan bahwa suatu informasi harus berbentuk tulisan/asli, informasi dan dokumen elektronik dapat dikatakan sah apabila informasi atau dokumen tersebut dapat diakses, ditampilkan kembali dan dijamin keutuhannya serta dapat dipertanggungjawabkan maka informasi atau dokumen elektronik disamakn dengan alat bukti surat atau tulisan.Dalam pembuatan dokumen elektronik yang berdasar adanya suatu perjanjian atau transaksi elektronik tentunya juga harus dilengkapi dengan tandatangan elektronik atau digital signature, dengan adanya tandatangan elektronik atau digital maka akan melengkapi keabsahan suatu dokumen tersebut. Pengertian mengenai tandatangan elektronik diatur dalam penjelasan ketentuan umum UndangUndang Nomor 11 Tahun 2008 Tentang Informasi Dan Transaksi Elektronik adalah tandatangan yang terdiri atas informasi elektronik yang dilekatkan, terasosiasi atau terkait dengan informasi elektronik lainnya yang digunakan sebagai alat verifikasi dan autentikasi. Tandatangan elektronik memiliki kekuatan hukum dan akibat hukum yang sah apabila memenuhi persyaratan seperti yang diatur dalam Pasal 11 ayat (1) UU ITE. Hasil dari cetakan Sertipikat Hak Tanggungan Elektronik adalah berupa dokumen elektronik yang dilengkapi dengan tanda tangan elektronik atau digital signature oleh Kepala Kantor Badan Pertanahan setempat. Tujuan pemberian tandatangan elektronik pada dokumen elektronik adalah untuk memastikan keaslian atau otentisitas dari dokumen tersebut dan sebagai bukti bahwa telah menerima atau menyetujui isi dari sebuah tulisan tersebut.

Kekuatan pembuktian tandatangan elektronik pada dokumen elektronik memiliki kepastian hukum atau kekuatan pembuktian yang sama dengan tandatangan basah atau manual yang dijelaskan dalam Peraturan Menteri Agraria Dan Tata Ruang/ Kepala Badan Pertanahan Nasional Republik Indonesia Nomor 3 Tahun 2019 Tentang Penerapan Tandatangan Elektronik Pasal 3 ayat (3) yang berbunyi " tandatangan elektronik memiliki kekuatan hukum 
dan akibat hukum yang sama dengan tandatangan secara manual".Sehingga pembuktian sertipikat hak tanggungan elektronik atau disebut juga HT-el di peradilan dalam bentuk Dokumen Elektronik memiliki kekuatan hukum atau kepastian hukum yang sama dengan dokumen biasa atau dokumen yang dibuat secara manual,Karena alat bukti elektronik berupa dokumen elektronik dipersamakan dengan alat bukti berupa dokumen tertulis (surat) sebagaimana diketahui bahwa kekuatan pembuktian dokumen tertulis (surat) sebagai alat bukti terletak pada keasliannya, oleh karena itu alat bukti dalam bentuk dokumen elektronik harus sama dan sesuai dengan aslinya.

Kekuatan pembuktian yang melekat pada alat bukti elektronik, oleh Undang-Undang Nomor 11 Tahun 2008 Tentang Informasi Dan Transaksi Elektronik yang menyatakan bahwa dokumen elektronik disetarkan dengan dokumen yang dibuat diatas kertas. Dalam hal ini dapat ditarik pemikiran bahwa kekuatan pembuktian dokumen elektronik dalam praktik perkara perdata dipersamakan dengan kekuatan alat bukti tulisan (surat). ${ }^{7}$

Sehingga hasil cetakan dari sertifikat hak tanggungan elektronik yang berupa dokumen elektronik memiliki kepastian hukum yang mampu melindungi masyarakat dari perbuatan hukum, dikarenakan dokumen elektronik merupakan perluasan dari alat bukti yang memiliki kekuatan pembuktiannya sama dengan alat bukti surat. Dokumen

${ }^{7}$ Denira Palmanda Sedana \& I Gusti Ayu Agung Ari Krisnawati, "Kedudukan Dan Kekuatan Surat Elektronik Sebagai Alat BuktiDalam Hukum Acara Perdata", JurnalHukum, Fakultas Hukum Universitas Udayana, h. 8 elektronik menjadi perluasan alat bukti dari perkembangan teknologi, adanya pengaturan mengenai dokumen elektronik sebagai alat bukti yang sah diatur pada Undang-Undang Nomor 11 Tahun 2008 Tentang Informasi Dan Transaksi Elektronik Pasal 5 ayat (2), agar menjadi alat bukti yang sah dokumen tersebut harus memenuhi persyaratan yang diatur pada UndangUndang Nomor 11 Tahun 2008 Tentang Informasi Dan Transaksi Elektronik Pasal 6. Peraturan mengenai bukti elektronik saat ini telah memberikan perlindungan hukum terhadap pihakpihak yang terkait didalamnya. Para pihak mendapatkan perlindungan hukum dari Undang-Undang Nomor 11 Tahun 2008 Tentang Informasi Dan Transaksi Elektronik (Undang-Undang Nomor 19 Tahun 2016 Tentang Perubahan Atas Undang-Undang Nomor 11 Tahun 2008 Tentang Informasi Dan Transaksi Elektronik), sehingga sertipikat hak tanggungan yang berupa hasil cetak dari dokumen elektronik dapat diajukan sebagai alat bukti di pengadilan.Semenjak diterbitkannya Peraturan Menteri Agraria Dan Tata Ruang/Kepala Badan Pertanahan Nasional Republik Indonesia Nomor 9 Tahun 2019 atau biasa disebut juga Permen No 9/2019 tentang Pelayanan Hak Tanggungan Terintegrasi Secara Elektronik banyak mengubah kebiasaan yang dilakukan dalam pendaftaran hak tanggungan, yang dimulai dari pendaftaran dilakukan secara online atau elektronik, Pejabat Pembuat Akta Tanah (PPAT) hanya mendaftarkan akta pemberian hak tanggungan secara elektronik, hasil sertipikat hak tanggungan berupa dokumen elektronik, kreditur yang berkewajiban melakukan pendaftaran

hak tanggungan secara online melalui sistem elektronik yang telah tersedia dengan syarat sudah terdaftar sebagai pengguna. Debitur harus atas nama 
pemilik agunan, pembayaran PNBP yang dilakukan oleh kreditur yang semula dilakukan pihak Pejabat Pembuat Akta Tanah (PPAT), Banyaknya perubahan yang terjadi tentunya membuat para pihak yang terlibat masih belum memahami mengenai pendaftaran hak tanggungan secara elektronik tentunya dalam teknis pendaftarannya, mengingat masih banyaknya masyarakat Indonesia yang gagap teknologi.

Dalam teknis pendaftaran jaminan hak tanggungan secara elektronik terdapat beberapa kendala diantaranya adalah : jaringan susah diakses, sistem yang bermasalah saat sedang melakukan pendaftaran secara elektronik atau online dikarenakan banyaknya pengguna yang menggunakannya dalam kurun waktu yang bersamaan serta sistem yang belum berfungsi sebagaimana mestinya.Belum lagi permasalahan yang ditimbulkan oleh hackeryang sengaja memasukkan virus kedalam sistem atau website hak tanggungan online yang menyebabkan data pribadi bocor dan hilangnya dokumen elektronik yang ada pada sistem, rentannya alat bukti elektronik yang diubah dan dipalsukan oleh pihak yang tidak bertanggung jawab.Keuntungan dalam pemberlakuan sistem Hak Tanggungan Elektronik jelas mempermudah dalam pendaftarannya, akan tetapi seperti yang tercantum dalam pasal 19 ayat (2) Peraturan Menteri Agraria Dan Tata Ruang/Kepala Badan Pertanahan Nasional Republik Indonesia Nomor 9 Tahun 2019 yang berbunyi "Permohonan perbaikan sertipikat hak tanggungan sebagaimana dimaksud pada ayat (1) diajukan melalui sistem HT-el paling lama 30 (tiga puluh) hari sejak tanggal Sertipikat Hak Tanggungan diterbitkan". Dalam pasal 19 ayat (1) menyatakan apabila terdapat kesalahan pengisian data dalam permohonan pelayanan hak tanggungan melalui sitem HT-el yang dimana telah diterbitkan sertipikat hak tanggungan dapat diperbaiki dengan ketentuan yang tercatat pada pasal 19 ayat (2) yang dimana berpotensi menimbulkan masalah baru bukannya mempermudah malah jadi mempersulit pihak pendaftar itu sendiri yang harus melaporkannya terlebih dahulu bahwa terdapat kesalahan dalam pengisian data yang dimana dalam memperbaikinya memakan waktu yang lama. Sehingga perlunya kembali Pemerintah untuk mengkaji ulang mengenai Peraturan tersebut agar tidak terjadi tumpang tindih dengan peraturan yang ada sebelumnya yang memiliki ketentuan lebih tinggi diatasnya serta mengurangi adanya kekosongan hukum dan memastikan adanya kepastian hukum dalam perkembangan zaman sekarang khususnya dalam dunia teknologi dan informasi dalam Hukum Formal.

\section{KESIMPULAN}

Kedudukan alat bukti elektronik sebagai alat bukti berdasarkan UndangUndang No 11 Tahun 2008 Tentang Informasi \& Transaksi Elektronik sesuai dengan Pasal 5 ayat (1) yang menyatakan bahwa semua Informasi Elektronik \&Dokumen Elektronik beserta hasil cetakannya merupakan alat bukti yang sah, sehingga kedudukan alat bukti elektronik dapat dipergunakan dalam

praktik perkara di persidangan sebagai alat bukti serta adanya perluasan mengenai alat bukti di luar Kitab Undang-Undang Hukum Perdata, namun tetap menjadi alat bukti yang sah apabila memenuhi syarat yang diatur oleh undang-undang.

Hasil dari Sertifikat Hak Tanggungan Elektronik adalah berupa cetakan dokumen elektronik. Pembuktian Sertipikat Hak Tanggungan Elektronik atau dikenal sebagai HT-el di pengadilan dalam bentuk Dokumen Elektronik memiliki kekuatan hukum dan akibat hukum yang sama dengan 
dokumen tertulis (surat), karena dalam dokumen elektronik juga mencantumkan adanya tandatangan elektronik atau digital signature. Tandatangan elektronik inilah juga memiliki kekuatan hukum yang sama dengan tandatangan basah. Peraturan mengenai bukti elektronik saat ini telah memberikan perlindungan hukum terhadap pihakpihak yang terkait didalamnya. Para pihak mendapatkan perlindungan hukum dari Undang-Undang Nomor 11 Tahun 2008 Tentang Informasi Dan Transaksi Elektronik (Undang-Undang Nomor 19 Tahun 2016 Tentang Perubahan Atas Undang-Undang Nomor 11 Tahun 2008 Tentang Informasi Dan Transaksi Elektronik, sehingga sertipikat hak tanggungan yang berupa hasil cetak dari dokumen elektronik dapat diajukan sebagai alat bukti di pengadilan.

\section{E. DAFTAR BACAAN}

\section{Buku-Buku}

Efa Laela Fakhriah, Bukti Elektronik Dalam Sistem Pembuktian Perdata, Refika Aditama, Bandung, 2017

I Ketut Oka Setiawan, Hukum Pendaftaran \& Hak Tanggungan, Sinar Grafika, Jakarta, 2019

Riky Rustam, Hukum Jaminan, UII Press, Yogyakarta, 2017

\section{Perundang-Undangan}

Kitab Undang-Undang Hukum Perdata. Undang-Undang Dasar Negara Republik Indonesia Tahun 1945

Undang-Undang Nomor 19 Tahun 2016 Tentang Perubahan Atas UndangUndang Nomor 11 Tahun 2008 Tentang Informasi Dan Transaksi Elektronik.
Undang-Undang Nomor 8 Tahun 1997 Tentang Dokumen Perusahaan.

Undang-Undang Nomor 4 Tahun 1996 Tentang Hak Tanggungan.

Peraturan Menteri Agraria Dan Tata Ruang/Kepala Badan Pertanahan Nasional

Republik Indonesia Nomor 3

Tahun 2019 Tentang Penerapan Tanda

Tangan Elektronik.

Peraturan Menteri Agraria Dan

Tata Ruang/Kepala Badan Pertanahan Nasional Republik Indonesia Nomor 9 Tahun 2019 Tentang Pelayanan Hak Tanggungan Terintegrasi Secara Elektronik.

\section{Jurnal Hukum}

Denira Palmanda Sedana \& I Gusti Ayu Agung Ari Krisnawati, "Kedudukan Dan Kekuatan Surat Elektronik Sebagai Alat Bukti Dalam Hukum Acara Perdata", Jurnal Hukum, Fakultas Hukum Universitas Udayana

\section{Media Daring}

Danginpuriandpartner, "Pengertian Hukum Acara Perdata Menurut Pakar", Wordpress, dalam https://http716.wordpress.com/20 16/10/30/pengertian-hukumacara-perdata-menurut-pakar/, diakses pada tanggal 20 Juli 2020.

Ilham, Mughnifar , "Pengertian Hukum Formil dan Hukum Materil", dalam https://www.materi.carageo.com/ pengertian-hukum-formal-danhukum-material/, diakses pada tanggal $20 \quad$ Juli 2020. 